\title{
Dalītā īpašuma tiesiskais regulējums un tā attīstības perspektīvas: problēmjautājumi saistībā ar daudzdzivokḷu dzīvojamām mājām no patērētāju tiesību aizsardzības skatupunkta
}

\author{
Zanda Dāvida \\ Biznesa augstskola "Turība", \\ Tiesību zinātṇu katedra, Latvija \\ Zanda.Davida@hotmail.com
}

\section{Kopsavilkums}

Rakstā apskatīts dalītā īpašuma (zemes un daudzdzīvokḷu dzīvojamās mājas) tiesiskais regulējums, tā problēmjautājumi un attīstības perspektīvas no patērētāju tiesību aizsardzības skatupunkta un ierosināts stiprināt ēkas un zemes vienotības principu attiecībā uz daudzdzīvokḷu dzīvojamām mājām un to dzīvokḷu îpašniekiem kā patērētājiem.

Atslēgvārdi: zemes noma, patērētājs, daudzdzivokḷ dzīvojamā māja, dzīvokḷa ipašnieks, zemes īpašnieks, dalītais īpašums.

\section{levads}

2017. gadā sabiedrībā ir īpaši aktualizējies jautājums par daudzdzīvokḷu dzīvojamo māju piespiedu zemes nomas tiesisko regulējumu un tā atbilstību mūsdienu sabiedrības vajadzībām. Tas ir saistīts gan ar to, ka 2016. gada 17. marta Saeimas sēdē tika pieñemts likumprojekts "Piespiedu dalītā īpašuma tiesisko attiecību privatizètajās daudzdzīvokḷu mājās izbeigšanas likums" 1. lasījumā, gan ar to, ka vairāki uzṇēmumi šogad ir sākuši agresīvi pieprasīt piespiedu zemes nomas maksu no daudzdzìvokḷu dzīvojamo māju dzīvokḷ i ipašniekiem par laika periodu, sākot no 2008. gada 1. janvāra, t. i., deviṇus gadus vecu zemes nomas maksu. Šie fakti liecina, ka pašlaik spēkā esošais daudzdzīvokḷu dzīvojamo māju piespiedu zemes nomas tiesiskais regulējums ir morāli novecojis un neatbilst sabiedrības vajadzībām. Tiesiski sarežğîta situācija Latvijā ir ne vien attiecībā uz privatizētajām daudzdzīvokḷu dzīvojamām mājām (kur starp pusēm pastāv piespiedu dalītā īpašuma tiesiskās attiecības), bet drīzumā aktuāls varētu kḷūt jautājums par tiesisko un 
ekonomisko nelīdzsvarotību starp krīzes laikā uzbūvēto daudzdzīvokḷu dzīvojamo māju dzīvokḷu ìpašniekiem un zemes īpašniekiem, kas peḷnas gūšanas nolū kā ir piekrituši savas zemes apbūvei ar daudzdzīvokḷu dzīvojamo māju (kur starp pusēm pastāv "brīvprātīgās" dalītā īpašuma tiesiskās attiecības).

Darba mērḳis - konstatēt galvenās tiesiskās problēmas un piedāvāt tiesiskā regulējuma pilnveidošanu, lai izbeigtu dalīto ìpašumu (kurā èka ir daudzdzīvokḷu dzīvojamā māja) gan attiecībā uz piespiedu, gan brīvprātīgo zemes nomu. - konstatēt galvenās tiesiskās problēmas un piedāvāt tiesiskā regulējuma pilnveidošanu, lai izbeigtu dalīto īpašumu (kurā ēka ir daudzdzìvokḷu dzīvojamā māja) gan attiecībā uz piespiedu, gan brīvprātīgo zemes nomu.

Publikācijas sagatavošanai galvenokārt izmantota vēsturiskā, analītiskā un salīdzinošā zinātniski pētnieciskā metode.

\section{Speciālais tiesību subjekts}

Pašlaik spēkā esošā zemes nomas (attiecībā uz daudzdzīvokḷu dzīvojamām mājām) tiesiskā regulējuma neefektivitāte, neatbilstība sabiedrības vajadzībām un vispārīgajiem, mūsdienās aktuālajiem tiesību principiem ir saistīta ar to, ka likumdevējs, piennemot šīs tiesību normas, nav ñēmis vērā šajās attiecībās iesaistìto speciālo tiesību subjektu, proti, daudzdzīvokḷu dzīvojamās mājas dzīvokḷa īpašnieku.

Centrālās statistikas pārvaldes veiktais pētỉjums liecina, ka 68 \% Latvijas iedzīvotāju 2011. gadā dzīvoja daudzdzīvokḷu dzīvojamā mājā, Rīgā - pat 92,6 \% [1]. Pēc Valsts zemes dienesta 2015. gada Nekustamo ìpašumu tirgus pārskata zemes noma skar aptuveni 3300 daudzdzīvokḷu dzīvojamo māju, kurās ir aptuveni 100000 dzīvokḷu. Savukārt zemes noma, uz kuras atrodas daudzdzīvokḷu mājas, skar aptuveni 3000 zemes vienību [13, 5]. Līdz ar to pirmšķietami secināms, ka zemes nomas (gan piespiedu, gan brīvprātīgās) skarto Latvijas iedzīvotāju skaits ir ievērojams, jo īpaši lielajās Latvijas pilsētās - Rigā, Daugavpilī, Jūrmalā, Jelgavā un Ogrē $[13,5]$.

Daudzdzīvokḷ dzīvojamās mājas un dzīvokḷa jēdzieni tiek skaidroti vairākos normatīvajos aktos, piemēram, likuma "Par valsts un pašvaldību dzīvojamo māju privatizāciju" pirmajā pantā [11], Dzīvokḷa īpašuma likuma otrajā pantā [3], kā arī tie ir analizēti tiesu praksē, piemēram, Latvijas Republikas Augstākās tiesas Senāta Administratīvo lietu departamenta 2011. gada 24. janvāra spriedumā lietā Nr. A42432505 (SKA49/2011) [7]. Analizējot tiesību avotus, secināms, ka daudzdzīvokḷu dzīvojamās mājas un dzīvokḷa pamatfunkcija ir nodrošināt fiziskas personas dzìvošanu mājsaimniecībā. Tas, ka daudzdzīvokḷu dzīvojamā mājā ir arī telpas, kuras netiek izmantotas dzīvošanai, piemēram, mākslinieku darbnīcas, neapdzìvojamās telpas (pagrabs, autostāvvieta u. tml.), nemaina daudzdzìvokḷu dzīvojamās mājas pamatfunkciju un statusu. Augstākā tiesa ir norādījusi, ka neapdzīvojamās ēkas likuma "Par valsts un pašvaldību dzīvojamo māju privatizāciju" izpratnē ir specifiska rakstura ēkas, kas paredzētas noteiktu publisku funkciju veikšanai. Apstāklis, ka ēkā līdztekus dzīvoklim atrodas arī neapdzīvojamās 
telpas, kas var tikt izmantotas, piemēram, kā tirdzniecības telpas, nenozīmē, ka šāda èka tādēl vien atzīstama par neapdzīvojamu ēku [7, 8]. Katrs gadījums ir jāvērtē individuāli, bet pamatprincipam, nosakot daudzdzīvokḷu dzīvojamās mājas statusu, būtu jābūt vērstam uz dzīvokḷa īpašnieka kā speciāla tiesību subjekta aizsardzību. Piemēram, ja daudzdzīvokḷu èkā ir tikai viens dzīvoklis, bet pārējie dzīvokḷi ir pārveidoti (un tiem ir mainits statuss uz neapdzivojamo telpu) par birojiem, veikaliem u. tml., nav pamata vienīgā dzīvokḷa īpašnieka tiesību ierobežojumam, neatzīstot māju par daudzdzīvokḷu dzīvojamo ēku. Praksē ir novērots gadījums, kad viesnīca faktiski tiek izmantota kā daudzdzīvokḷ lu dzīvojamā ēka un tās numuriṇi kā dzīvokḷi tiek pārdoti fiziskām personām (patērētājiem). Arī šādos gadījumos, kaut arī Zemesgrāmatā èkas statuss ir viesnīca, tiesību piemērotājiem nebūtu pamata tiesību normas tulkot šauri un gramatiski, tādējādi liedzot šīs ēkas dzīvokḷu īpašniekiem specifisko patērētāju tiesību regulējošo normatīvo aktu aizsardzību.

Daudzdzìvokḷ dzīvojamās mājas dzīvokḷu īpašnieki a priori ir atzīstami par patērētājiem Patērētāju tiesību aizsardzības likuma 1. panta 3. punkta izpratnē. Proti, patērētājs ir fiziska persona, kas izsaka vēlēšanos iegādāties, iegādājas vai varētu iegādāties vai izmantot preci vai pakalpojumu nolūkam, kurš nav saistìts ar tās saimniecisko vai profesionālo darbību [12]. Par pakalpojumu dzīvokḷa īpašniekam ir uzskatāmi ne vien pārvaldnieka sniegtie apsaimniekošanas pakalpojumi, elektroenerğijas tirgotāja sniegtie elektroenerğijas pakalpojumi u. tml., bet arī zemes nomas pakalpojumi, kurus sniedz zemes īpašnieki neatkarīgi no tā, vai tā ir piespiedu zemes noma vai brīvprātīgā zemes noma. Savukārt zemes ìpašnieki $a$ priori vispārīgos gadījumos (ja netiek pierādìts pretējais) ir atzīstami par pakalpojuma sniedzējiem Patērētāju tiesību aizsardzības likuma 1. panta 4. punkta izpratnē, jo tie atbilstoši savai saimnieciskajai vai profesionālajai darbībai sniedz pakalpojumu patērētājiem [6]. İpaši tas attiecas uz gadỉjumiem, kad zemes īpašnieks ir iesaistījies zemes nomas attiecībās ar daudzdzīvokḷu dzīvojamās mājas dzīvokḷu īpašniekiem brīvprātīgi un apzināti, piemēram, nopērkot zemes gabalu, uz kura atrodas daudzdzīvokḷu dzīvojamā māja. Pēc Valsts Zemes dienesta datiem 2015. gadā tikai 10 \% gadījumu zemes īpašniekiem dalītā īpašuma situācija radās no viṇa neatkarīgu apstākḷu dẹl, t. i., zemes īpašuma tiesību atjaunošanas gadījumos [13, 15]. Pārējos gadījumos zemes ìpašnieks pats ir pircis zemi, pienēēmis dāvinājumu, mantojis u. tml., jau apzinoties, ka uz zemes atrodas daudzdzīvokḷu dzīvojamā māja. Tas, ka šāda veida zemes īpašums ir naudas plūsmu generējošs investīciju objekts, kurā zemes ìpašniekam gandrīz nav jāiegulda papildu darbs, atzīst gan privātie tiesību subjekti, gan valsts institūcijas $[13,15]$. Lìdz ar to uz dzīvokḷu īpašnieku kā patērētāju un zemes īpašnieku kā pakalpojumu sniedzēju zemes nomas tiesiskajām attiecībām ir jāraugās no patērētāju tiesību aizsardzības regulējuma prizmas.

Direktīvas par negodīgiem noteikumiem patērētāju līgumos [4] ieviestā aizsardzības sistēma balstās uz ideju, ka patērētājs salīdzinājumā ar pakalpojuma sniedzēju atrodas vājākā pozīcijā, kas attiecas gan uz iespēju risināt sarunas, gan uz informētības līmeni [5]. Lai gan vēsturiski patērētāja kā vājākās puses tiesību koncepts ir radies attiecībā 
uz līgumiem, kas tiek slēgti starp patērētāju un pakalpojumu sniedzēju, mūsdienās prakse liecina, ka šo konceptu atzīst daudzi tiesību piemērotāji un to ir nepieciešams attiecināt arī uz citiem tiesību institūtiem, kuros ir iesaistīti patērētāji, piemēram, daudzdzīvokḷu dzīvojamo māju zemes nomas gadījumos. Ne visos gadījumos starp zemes īpašnieku un dzīvokḷu īpašniekiem pastāv zemes nomas līguma attiecỉbas klasiskā izpratnē. Uz tiesas sprieduma pamata nodibinātās zemes nomas attiecības vai ar konkludentām darbībām uz likuma pamata nodibinātās zemes nomas attiecības ir vērtējamas kā līgumattiecības ar visām no tām izrietošajām sekām. Līdz ar to uz šo tiesību subjektu starpā nodibinātajām zemes nomas attiecībām ir jāpiemēro patērētāja kā vājākas puses tiesību koncepts neatkarīgi no tā, vai šìs attiecības ir nodibinātas piespiedu kārtā, brīvprātīgā kārtā vai ar tiesas starpniecību.

\section{Pušu nespēja vienoties par zemes nomas līgumu}

Viena no galvenajām problēmām, kas ir radusies no zemes nomas attiecībām starp zemes un dzīvokḷu īpašniekiem (īpaši piespiedu zemes nomas gadījumos), ir nespēja pusēm savstarpēji vienoties par zemes nomas līgumu, tā noteikumiem un galvenokārt par zemes nomas maksas apmēru. Saskaṇā ar pēdējā laikā pausto valsts iestāžu viedokli dzīvojamās mājas īpašniekiem saistošs pienākums veikt konkrētus maksājumus zemes īpašniekiem var pastāvēt, ja ir notikusi dzīvojamās mājas īpašnieku vienošanās ar zemes īpašnieku par piespiedu zemes nomas tiesisko attiecību noregulēšanu vai arī ir spēkā stājies tiesas spriedums, kurā šĩs attiecības ir konstatētas un noteiktas to būtiskās sastāvdaḷas, jo tikai tad var uzskatīt, ka ir nodibināta saistību tiesība, kurā dzīvojamās mājas īpašniekam ir pienākums veikt konkrētus maksājumus zemes īpašniekiem. Tā kā nomas maksu kā nomas būtisko sastāvdaḷu nosaka tiesisks darījums vai tiesas spriedums, kamēr viena no tiem nav, nav iespējams noteikt nomas maksas apmēru [9]. Izvērtējot likuma "Par zemes reformu Latvijas Republikas pilsētās" 12. pantu, likuma "Par valsts un pašvaldïbu dzīvojamo māju privatizāciju” 50. panta pirmās daḷas 3. punktu, 54. pantu, Dzīvojamo māju pārvaldǐšanas likuma 17. ${ }^{2}$ un 17. ${ }^{7}$ pantu kopsakarā ar citiem tiesību avotiem, tai skaitā vispārīgajiem tiesību principiem un tiesību konceptu par patēētāju kā vājāko subjektu (salīdzinot ar profesionālu pakalpojuma sniedzēju), secināms, ka primāri iniciatīva par zemes nomas līguma noslēgšanu ir jāizrāda zemes ipašniekam. Proti, likuma "Par valsts un pašvaldību dzīvojamo māju privatizāciju" 54. panta ceturtā daḷa īpaši akcentē zemes ìpašnieka tiesības celt prasību tiesā par zemes nomas līguma noslēgšanu, ja puses pirms tam nav spējušas vienoties par zemes nomas līgumu. Šāda veida tiesības likumdevējs nav īpaši noteicis dzīvokḷu īpašniekiem, bet tās izriet no vispārīgajām jebkuras personas tiesībām uz aizsardzību tiesā regulējuma. Nemot vērā minēto un to, ka vispārīgi patērētājs ir atzīstams par vājāko subjektu (salīdzinot ar profesionālu pakalpojuma sniedzēju, t. i., zemes īpašnieku, kura mērḳis ir gūt peḷnu no zemes nomas), kā arī to, ka zemes īpašniekam ir daudz vieglāk vērsties pie daudzdzīvokḷu mājas dzīvokḷa īpašniekiem vai to pilnvarotās personas (nekā vairākiem desmitiem vai pat simtiem dzīvokḷu 
īpašnieku vienoties par vēršanos pie zemes īpašnieka), secināms, ka zemes īpašnieka pienākums saskaṇā ar labas ticības principu ir darìt visu iespējamo, lai ar dzīvokḷa ìpašniekiem vai to pilnvaroto personu vienotos par zemes nomas līguma noslēgšanu. Tādējādi prakse, tieši (t. i., bez vēršanās pie dzīvokḷa īpašniekiem ar piedāvājumu noslēgt zemes nomas līgumu) piemērojot un arī pieprasot no dzīvokḷu ỉpašniekiem zemes nomas maksu $6 \%$ apmērā no zemes kadastrālās vērtības uz likuma pamata nav atzīstama par labu, profesionālu un tiesisku. Gadījumā, ja pēc zemes īpašnieka iniciatīvas noslēgt zemes nomas līgumu neizdodas, zemes īpašniekam pirms likumā noteiktās nomas maksas apmēra pieprasī̌sanas ir pienākums vērsties tiesā, lūdzot tiesas palīdzību nodibināt starp pusēm piespiedu zemes nomas saistības. Šādā situācijā tiesa arī izvērtēs zemes nomas maksas apmēru, jo ne visos gadījumos ir pamats konkrētam zemes gabalam piemērot maksimālo likumā noteikto zemes nomas maksu $6 \%$ apmērā no zemes kadastrālās vērtības. Vienlaikus tiesas kompetencē ir tiesības izlemt, kura no pusēm (dzīvokḷu īpašnieki vai zemes īpašnieks) veiks obligāti veicamās pārvaldī̌anas darbības attiecībā uz piesaistīto zemes gabalu saskañā ar Dzīvojamās mājas pārvaldīšanas likuma 6. panta otro dalu.

Pašlaik praksē publiski aktualizējušies gadījumi liecina par citādu zemes īpašnieku rīcību. Proti, zemes īpašnieks pat nemēgina piedāvāt daudzdzīvokḷu dzīvojamo māju dzīvokḷu īpašniekiem iespēju noslēgt zemes nomas līgumu, nevēršas arī tiesā par tiesisko attiecību nodibināšanu, bet uzreiz vēršas pie dzīvokḷu īpašniekiem ar izrakstītiem rēkiniem, nosakot zemes nomas maksas maksimālo likumā aț̣auto apmēru, proti, 6 \% gadā no zemes kadastrālās vērtỉbas. Šāda prakse nav labticīga, jo pusēm, pirmkārt, ir jāmēgeina vienoties par zemes nomas maksu, ievērojot lietas īpašos apstākḷus, jo ne visos gadïjumos zemes īpašums ir tik kvalitatīvs, vērtīgs un sakopts, lai zemes ipašniekam būtu pamats saṇemt maksimālo zemes nomas maksas apmēru. Vienlaikus zemes īpašniekam būtu jāṇem vērā arī ēkai nepieciešamais funkcionāli piesaistītais zemes gabals, zemesgabala kadastrālā vērtība un ēkas lielums (dzīvokḷu skaits èkā), jo zemes nomas maksa vienam dzīvokḷa īpašniekam nedrīkstētu būt nesamērīgi liela un paverdzinoša, piemēram, salīdzinot ar dzīvokḷa ìpašuma tirgus vērtību, pat ja zemes nomas maksa iekḷaujas likumā noteiktajos $6 \%$.

Nemot vērā pašreizējo situāciju Latvijā, var paredzēt, ka drīzumā varētu aktualizēties jautājums par tiesisko un ekonomisko nelīdzsvarotību starp krīzes laikā uzbūvēto daudzdzìvokḷu dzīvojamo māju dzīvokḷu īpašniekiem un zemes īpašniekiem, kuri peḷnas gūšanas nolūkā ir piekrituši savas zemes apbūvei ar dzīvojamo māju. Praksē parasti zemes nomas līgumos puses ir vienojušās par 10 gadu līguma terminuu, tāpēc šajās attiecībās radīsies nepieciešamība pārslēgt līgumus vai pagarināt to terminu. Tas atkal novedīs sabiedrību, tiesību piemērotājus un iesaistìtās puses pie strīdiem, kas pašlaik ir aktualizējušies tieši piespiedu zemes nomas attiecību gadījumos - vai iznomātās zemes nomas maksa ir adekvāta un pamatota. İpaši jāuzsver, ka brīvprātīgajos zemes nomas līgumos zemes nomas maksa mēdz būtiski pārsniegt likumiskos 6 \% gadā no zemes kadastrālās vērtības un bieži vien zemes nomas maksas apmērs nav ekonomiski pamatots un samērīgs. 
Līdz ar to var uzdot retorisku jautājumu - vai Latvijas sabiedrībai un tiesību sistēmai ir nepieciešams veicināt zemes un daudzdzīvokḷ u dzīvojamās èkas dalījumu, tā turpināšanos un jaunu šāda veida attiecību rašanos? Nemot vērā iepriekš iztirzātos argumentus un turpmāk minēto, atbilde uz šo jautājumu ir noliedzoša.

\section{Izṇēmums no zemes un ēkas vienotības principa}

Civillikuma 968. pants nosaka zemes un ēkas vienotības principu [2]. Savukārt likuma "Par atjaunotā Latvijas Republikas 1937. gada Civillikuma ievada, mantojuma tiesību un lietu tiesību daḷas spēkā stāšanās laiku un piemērošanas kārtību" 14. panta pirmā dal̦a paredz izṇēmumu no zemes un ēkas vienotības principa, nosakot gadījumus, kad ēka ir uzskatāma par patstāvīgu îpašuma objektu. Šì izṇēmuma nepieciešamība radās vēsturisku notikumu ietekmē, proti, ìstenojot zemes reformu pēc Latvijas Republikas neatkarības atjaunošanas. Toreiz likumdevējs izšķīrās par izṇēmuma no zemes un ēkas vienotības principa noteikšanu, taču pašlaik var uzskatìt, ka minētā izṇēmuma pastāvēšanas veicināšana, īpaši attiecībā uz daudzdzīvokḷ dzīvojamo māju dzīvokḷu īpašnieku un zemes īpašnieku attiecībām, rada virkni juridisku un praktisku problēmu, kā arī šis izṇēmums vairs nav nepieciešams, jo praktiski vairs nepastāv vēsturisko notikumu seku pamatojums. To apstiprina Valsts Zemes dienesta pētỉjums, kurā konstatēts, ka 2015. gadā tikai $10 \%$ gadījumu zemes īpašniekiem dalītā īpašuma situācijas pamatā ir zemes ìpašuma tiesỉbu atjaunošana $[13,15]$.

Pašreiz spēkā esošais tiesiskais regulējums, kas dod iespēju dzīvokḷu īpašniekiem izbeigt zemes nomu, ir neefektīvs un praktiski gandrīz neizmantojams. Pirmpirkuma tiesību gadījumā vispārīgais Civillikuma regulējums (no 2060. līdz 2063. pantam) nav piemērots speciālajam tiesību subjektam - daudzdzivokḷu dzīvojamās mājas dzīvokḷu îpašniekam. Lai ỉpašnieku kopỉba pieņemtu lēmumu par pirmpirkuma tiesību izmantošanu vai par vienošanās slēgšanu ar zemes īpašnieku par zemes izpirkšanu, "par" ir jānobalso visiem dzīvokḷu ippašniekiem (sk. Dzīvokḷa īpašuma likuma 17. panta piekto daḷu [3]). Tas, ka, izmantojot pašreiz spēkā esošo normatīvo regulējumu, dzīvokḷu īpašnieku iespējas iegūt zemi savā ỉpašumā ir ḷoti ierobežotas, atzīst arī Tieslietu ministrija [10]. Tas ir motivējis izpildvaru izstrādāt likumprojektu "Piespiedu dalītā ỉpašuma tiesisko attiecību privatizētajās daudzdzīvokḷu mājās izbeigšanas likums", kas raksta tapšanas brīdi ir pieṇemts Saeimā 1. lasījumā 2016. gada 17. martā. Likumprojekta pieṇemšanas gadījumā nākotnē tas veicinās zemes un èkas vienotības principa stiprināšanu, bet nerisinās brīvprātīgās zemes nomas (ar ēku - daudzdzìvokḷu dzivojamo māju) problēmas. No pieredzes var secināt, ka brīvprātīgā zemes noma patstāvīgam īpašuma objektam - daudzdzīvokḷu dzìvojamai mājai - tiek dibināta, lai gūtu ilglaicīgu peḷnu no daudzdzīvokḷu dzīvojamo māju dzīvokḷu īpašniekiem. Parasti šīs nomas dibinātāji ir zemes īpašnieks un ēkas īpašnieks, kas uzbūvējis ēku, lai tās dzīvokḷus pārdotu fiziskām personām. Bieži vien patērētāji, iegādājoties šāda veida dzìvokḷu īpašumus, neaizdomājas un / vai nav pienācīgi informēti par tiesiskajām sekām, kas rodas gadỉjumos, ja zeme nepieder dzīvokḷu ìpašniekiem. 
Šāda veida darījumi īpaši aktuāli bija krīzes gados, un sabiedrībā ir dzirdēti secinājumi - ja èkas īpašnieks pārdod dzīvokḷus atsevišḳi no zemes, tas nozīmē, ka pārdevējs nav labticīgs un, visdrīzāk, dzīvokḷ ỉpašniekiem nākotnē radīs problēmas ne tikai ar zemes nomu, bet arī, piemēram, ar mājas tehnisko stāvokli, būs jāsaskaras ar būvniecības paviršībām u. tml. Ēkas nodalī̌̌ana no zemes bieži vien nav pamatota ar to, ka ēkas īpašnieks finansiāli nav varējis aț̣auties nopirkt zemi, bet gan ar ēkas un zemes īpašnieku vienošanos gūt ilgstošu peḷnu, "iejūdzot” dzīvokḷu ìpašniekus nebeidzamos maksājumos par zemes nomu. Var uzskatīt, ka šāda veida darbïbas no zemes un ëkas īpašnieku puses daudzdzīvokḷu dzīvojamo māju gadījumos jau robežojas ar augḷošanu Krimināllikuma 201. panta izpratnē [6], jo nelabticīgi tiek izmantota patērētāja nezināšana, neizpratne un viṇa ekonomiski, tiesiski un finansiāli vājākā pozīcija. Vācijas Civilkodeksa 138. pants regulē situācijas, kad darījums ir slēgts pretēji labiem tikumiem vai arī savtīgi izmantojot otra kontrahenta nevienlīdzīgo stāvokli, vai veicot augḷošanu. Šì panta otrā daḷa paredz: "It sevišḳi nav spēkā tāds darījums, caur ko kāds, izmantojot otra spiedīgu stāvokli, pieredzes, spriešanas vai gribasspēka trūkumu, par nesamērīgu pret izpildījumu panāk sev vai trešajai personai par labu apsolījumu vai garantiju kādam mantiskam labumam" [8].

Manuprāt, zemes un ēkas dalījums daudzdzīvokḷu dzīvojamās mājas gadījumā Latvijā nebūtu piel̦aujams ne piespiedu, ne brīvprātīgajā nomā.

\section{Secinājumi un priekšlikumi}

1. Daudzdzīvokḷu dzīvojamās mājas dzīvokḷu īpašnieki a priori (ja netiek pierādīts pretējais) ir atzīstami par patērētāiiem Patērētāju tiesību aizsardzības likuma 1. panta 3. punkta izpratnē, bet zemes ipašnieki - par pakalpojuma sniedzējiem saskanā ar Patērētāju tiesību aizsardzības likuma 1. panta 4. punktu. Tādējādi uz dzīvokḷu īpašnieku un zemes ipašnieku tiesiskajām attiecībām ir jāraugās no patēētāju tiesību aizsardzības regulējuma prizmas.

2. Starp dzīvokḷu īpašnieku un zemes īpašnieku nodibinātajām zemes nomas attiecībām ir jāpiemēro patērētāja kā tiesiski vājākās puses tiesību koncepts neatkarīgi no tā, vai šìs attiecības ir nodibinātas piespiedu kārtā (piespiedu zemes noma), brīvprātīgā kārtā (brīvprātīgā zemes noma) vai ar tiesas starpniecību.

3. Konstatējumiem, vērtējot daudzdzīvokḷu dzīvojamās mājas statusu, ir jābūt vērstiem uz dzīvokḷa īpašnieka kā speciāla tiesību subjekta aizsardzību. Tādējādi arī ēka, kurā ir tikai viens dzīvoklis un pārējās telpas, piemēram, tirdzniecības telpas, ir atzīstama par daudzdzīvokḷu dzīvojamo māju.

4. Primāri iniciatīva par zemes nomas līguma noslēgšanu ir jāizrāda zemes ìpašniekam. Tas ir zemes ìpašnieka imperatīvs pienākums, un tas ir priekšnosacījums, lai zemes īpašnieks varētu uzsākt citas likumā atḷautās darbības, piemēram, vērstos tiesā ar pieteikumu par zemes nomas attiecību nodibināšanu. 
5. Nomas maksu kā nomas būtisko sastāvdaḷu nosaka tiesisks darïjums vai tiesas spriedums; kamēr viena no tiem nav, nav iespējams noteikt nomas maksu. Tieša (t. i., bez vēršanās pie dzīvokḷu ìpašniekiem ar piedāvājumu noslēgt zemes nomas līgumu) zemes nomas maksas pieprasišsana no dzīvokḷu īpašniekiem 6 \% gadā no zemes kadastrālās vērtības (uz likuma pamata) ir vērtējama kā nelabticīga, neprofesionāla un negodīga prakse.

6. Ja puses nespēj vienoties par zemes nomas maksas apmēru, tad tās apmēru var izvērtēt tikai tiesa, jo ne visos gadïjumos zemes īpašums ir tik kvalitatīvs, vērtīgs un sakopts, lai zemes ippašniekam būtu pamats saṇemt likumā noteikto maksimālo zemes nomas maksas apmēru -6 \% gadā no zemes kadastrālās vērtības. Zemes nomas maksa vienam dzīvokḷa ìpašniekam nedrīkstētu būt nesamērīgi liela un paverdzinoša, pat ja tā iekḷaujas zemes nomas maksas likumā noteiktajā 6 \% apmērā no zemes kadastrālās vērtības.

7. Pašreiz spēkā esošais regulējums, kas dod iespēju dzīvokḷu ỉpašniekiem izbeigt zemes nomu, ir neefektīvs un praktiski gandrīz neizmantojams.

8. Ja tiks piennemts likumprojekts "Piespiedu dalītā ìpašuma tiesisko attiecību privatizētajās daudzdzīvokḷu mājās izbeigšanas likums", tas veicinās zemes un èkas vienotības principa stiprināšanu, bet nerisinās brīvprātīgas zemes nomas problēmas.

9. Lai novērstu tiesisko un ekonomisko nelīdzsvarotību starp dzīvokḷu īpašniekiem un zemes ipašniekiem, Latvijā nebūtu piel̦aujams daudzdzīvokḷu dzīvojamās mājas zemes un èkas dalījums ne piespiedu, ne brīvprātīgā nomā. Likumdevējam būtu ieteicams pien,emt tādu tiesisko regulējumu, kas veicinātu zemes un ēkas vienotības principa stiprināšanu, taču vienlaikus būtu taisnīgs un apmierinātu gan zemes īpašnieku, gan dzīvokḷu īpašnieku intereses.

\section{Legal Framework of the Share Property and Its Development Outlook: Issues of the Apartment House from Consumer Rights Protection Viewpoint}

\section{Abstract}

The author of the article looks at the legal framework of the share property (land and apartment house), problems and issues from the viewpoint of consumer rights. The author suggests sustain principle of the house and land unity, which is connected with an apartment house and an apartment owner as a consumer.

Keywords: land use, consumer, apartment house, apartment owner, land owner. 


\section{Avoti un literatūra}

1. Centrālās statistikas pārvaldes statistikas 2013. gada 21. jūnija apkopojums par 2011. gada tautas skaitî̌̌anu. Iegūts no: http://www.csb.gov.lv/notikumi/tikai-pieci-procenti-latvijasiedzivotaju-dzivo-pedejos-10-gados-uzceltajos-majoklos-3897-0 [sk. 19.04.2017.].

2. Civillikums. 28.01.1937. likums. Valdības Vēstnesis. 41, 20.02.1937. Stājies spēkā 01.09.1992. Konsolidētā redakcija iegūta no: https://likumi.lv/doc.php?id=225418 [sk. 19.04.2017.].

3. Dzīvokḷa īpašuma likums. 28.10.2010. likums. Latvijas Vēstnesis. 183 (4375), 17.11.2010. Stājies spēkā 01.01.2011. Konsolidētā redakcija iegūta no: https://likumi.lv/doc.php?id=221382 [sk. 19.04.2017.].

4. Eiropas Padomes 1993. gada 5. aprīḷa Direktīva 93/13/EEK par negodīgiem noteikumiem patērētāju līgumos. Eiropas Savienības Oficiālais Vēstnesis. L 095, 21.04.1993. Iegūts no: http:// eur-lex.europa.eu/legal-content/LV/TXT/?uri=CELEX\%3A31993L0013 [sk. 24.04.2017.].

5. Eiropas Savienības Tiesas spriedums lietā Nr. C-415/11, Aziz. 2013. gada 14. marts; Eiropas Savienības Tiesas spriedums lietā Nr. C-618/10, Banco Espanol de Credito SA. 2012. gada 14. jūnijs. Iegūts no: http://curia.europa.eu/jcms/jcms/j_6/lv/ [sk. 24.04.2017.].

6. Krimināllikums. 17.06.1998. likums. Latvijas Vēstnesis. 199/200 (1260/1261), 08.07.1998. Stājies spēkā 01.04.1999. Konsolidētā redakcija iegūta no: https://likumi.lv/doc.php?id=88966 [sk. 19.04.2017.].

7. Latvijas Republikas Augstākās tiesas Senāta Administratīvo lietu departamenta sprieduma lietā Nr. A42432505 (SKA-49/2011). 2011. gada 24. janvāris. Iegūts no: http://at.gov.lv/files/ uploads/files/archive/department3/2011/49.pdf [sk. 20.04.2017.].

8. Latvijas Republikas Augstākās tiesas 2008. gada apkopojums "Par Civillikuma 1415. panta piemērošanu". Iegūts no: http://at.gov.lv/lv/judikatura/tiesu-prakses-apkopojumi/civiltiesibas/ [sk. 23.04.2017.].

9. Latvijas Republikas Tieslietu ministrijas skaidrojams "Piespiedu nomas tiesisko attiecību aktuālie jautājumi”. 2017. gada 21. marts. Iegūts no: https://www.tm.gov.lv/lv/aktualitates/tminformacija-presei/piespiedu-nomas-tiesisko-attiecibu-aktualie-jautajumi-2 [sk. 23.04.2017.].

10. Likumprojekta "Piespiedu dalītā īpašuma tiesisko attiecību privatizētajās daudzdzīvokḷu mājās izbeigšanas likums” sākotnējās ietekmes novērtējuma ziṇojums (anotācija). Iegūts no: http:// titania.saeima.lv/LIVS12/saeimalivs12.nsf/0/CD1A6440A69EB8BAC2257ED1003CBA2C? OpenDocument [sk. 22.04.2017.].

11. Likums "Par valsts un pašvaldību dzīvojamo māju privatizāciju”. 21.06.1995. Likums. Latvijas Vēstnesis. 103 (386), 11.07.1995. Stājies spēkā 25.07.1995. Konsolidētā redakcija iegūta no: https://likumi.lv/doc.php?id=35770 [sk. 19.04.2017.].

12. Patērētāju tiesību aizsardzības likums. 18.03.1999. Likums. Latvijas Vēstnesis. 104/105 (1564/1565), 01.04.1999. Stājies spēkā 15.04.1999. Konsolidētā redakcija iegūta no: https:// likumi.lv/doc.php?id=23309 [sk. 20.04.2017.].

13. Valsts zemes dienests. Nekustamā īpašuma tirgus pārskats. 2015/1. Iegūts no: http://www.vzd. gov.lv/files/parskats_15052015_gala.pdf [sk. 20.04.2017.]. 